\title{
Inhalation experiments with extracts of Aspergillus fumigatus on patients with allergic aspergillosis and aspergilloma
}

\author{
E. A. M. STEVENS, C. H I L VER I N G, N. G . M . OR IE \\ Department of Medicine and Division of Pulmonary Diseases of the University Hospital, \\ State University, Groningen, The Netherlands
}

\begin{abstract}
A description is given of the reaction to inhalation of Aspergillus extract by seven patients with aspergillosis, including five with aspergillomas. The nature of, and possible causes for, such reactions are discussed on the basis of their resemblance to the symptomatology of the vegetable dust syndromes. The findings may contribute to a better understanding of the pathogenesis of fever in aspergillosis.
\end{abstract}

Pepys, Riddell, Citron, Clayton, and Short (1959), Biguet, Tran van Ky, Capron, and Fruit (1962), Gernex-Rieux, Biguet, Voisin, Capron, and Tran van Ky (1963), Gernez-Rieux, Biguet, Voisin, Capron, Balgairies, and Tran van Ky (1963), Longbottom, Pepys, and Clive (1964), and Longoottom and Pepys (1964) described methods for the immunological diagnosis of Aspergillus growth in the lungs. In the sera of patients, precipitating antibodies to Aspergillus were demonstrated with the aid of double diffusion techniques.

Pepys, Riddell, Citron, Clayton, and Short (1959) assigned to these precipitating antibodies a role in the pathogenesis of some of the symptoms of allergic aspergillosis. The 'late' reaction in the skin test, the pulmonary infiltrations, and the fever are supposed to be based on an Arthus reaction, i.e., a type III reaction, according to Gell and Coombs (1964).

Type III reactions are also held to be responsible for more or less identical symptoms in other lung diseases characterized by the presence of specific precipitating antibodies, namely farmer's lung (Parish, 1963 ; Bishop, Melnick, and Raine, 1963), pigeon breeder's lung (Reed, Sosman, and Barbee, 1965), bagassosis (Buechner, 1960), mushroom worker's disease (Bringhurst, Byrne, and Gershon-Cohen, 1959), and maple bark stripper's disease (Emanuel, Lawton, and Wenzel, 1962), grouped as vegetable dust syndromes (Gell and Coombs, 1964).

The existence of a type III reaction in allergic aspergillosis was questioned because the triad of 'late' skin reaction, pulmonary infiltrations, and fever is never found in patients with aspergilloma, although the level of precipitins in the sera of these patients is usually higher than in people suffering from allergic aspergillosis (Campbell and Clayton, 1964).

Recently, we have been able to observe two patients whose clinical picture might be attributable to a type III reaction as a result of the presence of aspergillomas (Hilvering, Stevens, and Orie, p. 19 of this issue). We have therefore tried to produce type III reactions by the inhalation of Aspergillus extract in patients with aspergillomas. A late reaction following such a challenge had already been demonstrated in patients with allergic aspergillosis. When this was also found to be possible in patients with aspergillomas, two patients with allergic aspergillosis were included in the investigation in order to compare the reaction patterns.

\section{METHODS}

DEMONSTRATION OF PRECIPITINS AGAINST ASPERGILLUS FUMIGATUS AND PREPARATIONS OF EXTRACTS OF THIS FUNGUS The preparation of mycelium extracts and double diffusion techniques have been described in a previous publication (Dijkman, Stevens, Hilvering, and Orie, 1968). There are only minor differences between these methods and those used by the authors referred to before. But it should be mentioned that the mycelium from which the extract was obtained was microscopically free from spores. This had been taken from a 21-day old culture (Raper and Fennell, 1965), whose medium contained the same nutrients as the liquid mycelium culture. The spores 
were obtained by shaking the culture with glass beads ( $3 \mathrm{~mm}$. diameter) and water, followed by centrifuging the suspension.

With the aid of a mechanical agate mortar the spore mass, which had previously been mixed with Carborundum 800 (I/I v/v), was destroyed. Subsequently, the destroyed spores were eluted with distilled water by means of a magnetic stirrer. After dialysis (48 hours' running water and 24 hours' distilled water) the extract was freeze-dried and dissolved at $100 \mathrm{mg} . / \mathrm{ml}$.

CHALlENGING At 8.30 a.m. the patients inhaled $30 \mathrm{mg}$. of spores or mycelium antigen dissolved in $5 \mathrm{ml}$. Coca solution, use being made of a mouth spray (Wiesbadener Doppelspray). Before and after inhalation, as well as at 4.30 p.m., the VC and $\mathrm{FEV}_{1}$ were determined (Lode Spirograph D $53 \mathrm{R}$ ).

At the same time blood gas analyses were carried out (Radiometer $\mathrm{PaO}_{2}$ membrane electrode type $\mathrm{E}$ 5046, $\mathrm{PaCO}_{2}$ membrane electrode type E 5036). Every day the rectal temperature was taken at 8 and 11 a.m., and at 2 and 5 p.m. leucocytes and eosinophilic cells in the capillary blood were counted. The patients were auscultated at regular intervals and the subjective findings were recorded.

All the patients were challenged with mycelium extract as well as with spore extract, these extracts being administered alternately. The challenges were separated by a control day, on which the same tests were performed but only Coca solution was inhaled.

On the days of the experiments all medication was stopped. Table I presents a few clinical data on the patients investigated.

\section{RESULTS}

With only a few exceptions all the parameters were determined on all the patients. In this connexion reference is made to Table II, which lists the symptoms found on challenging. On the days $\stackrel{\vec{s}}{+}$ of inhalation patient 2 took $10 \mathrm{mg}$. prednisone. Patient 4 , in view of his vigorous reaction to the 흘 first challenge, was not subjected to a second $\frac{\bar{c}}{\odot}$ challenge. After challenging, three different reac- $\stackrel{\mathbb{}}{\Omega}$ tions were observed:

(1) Reaction immediately following inhalation, $\vec{\circ}$ which corresponds to a type I reaction: expiratory dyspnoea with wheezing, a reduction of $\mathrm{PaO}_{2}$, and $\vec{\omega}$ a reduction of the $\mathrm{VC}$ and $\mathrm{FEV}_{1}$ (Fig. 1). This reaction was observed in patient 3 .

(2) Reaction occurring 4 to 6 hours after $\mathrm{G}^{-}$ inhalation. This reaction was very similar to the late reaction of farmer's lung patients after expo- $\overrightarrow{-}$ sure to a mouldy hay atmosphere (Hilvering, de Vries, and Orie, 1966) or after inhaling Thermopolyspora polyspora extract. This reac-c tion, together with the febrile reaction of allergic aspergillosis, is considered to be a type III reaction (Pepys et al., 1959; Gell and Coombs, 1964). We observed this reaction, consisting of dyspnoea, $\vec{\varphi}$ malaise, fever, crepitant râles, and reduced $\mathrm{PaO}_{2} \mathrm{O}$ and $\mathrm{PaCO}_{2}$ in patients 5, 6, and 7 (Fig. 2).

(3) Reaction, consisting of a combined early and late reaction, i.e., both type I and type III reactions, as is also found after inhalation in allergic aspergillosis patients. This reaction was\%

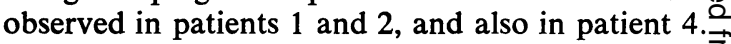
In patient 4 , however, the type I reaction was only을 slight and could be diagnosed through the lung function and blood gas values but not clinically? (Fig. 3)

Leucocytosis, an attendant phenomenon of the type III reaction, was observed in only two cases (patients 4 and 7). No eosinophilia was found. No differences were observed in the type or 3 intensity of the reaction in dependence on the

T A B L E I

CLINICAL DATA OF PATIENTS STUDIED

\begin{tabular}{|c|c|c|c|c|c|c|c|c|c|}
\hline $\begin{array}{l}\text { Patient } \\
\text { No. }\end{array}$ & Sex & Age & Diagnosis & Haemoptysis & $\begin{array}{c}\text { Transient } \\
\text { Shadows on } \\
\text { Chest } \\
\text { Radiograph }\end{array}$ & $\begin{array}{c}\text { Blood } \\
\text { Eosinophilia }\end{array}$ & $\begin{array}{l}\text { Precipitating } \\
\text { Antibodies } \\
\text { against } \\
\text { A. fumigatus }\end{array}$ & $\begin{array}{l}\text { Sputum } \\
\text { Cuilture for } \\
\text { A. fumigatus }\end{array}$ & $\begin{array}{c}\text { Immediate Type } \\
\text { I.D. Reaction } \\
\text { with } \\
\text { A. fumigatus }\end{array}$ \\
\hline 1 & $F$ & 59 & $\begin{array}{l}\text { CNSLD } \\
\text { Allergic } \\
\text { aspergillosis }\end{array}$ & + & + & + & + & + & + \\
\hline 2 & $\mathbf{M}$ & 41 & $\begin{array}{l}\text { CNSLD } \\
\text { Allergic } \\
\quad \text { aspergillosis }\end{array}$ & + & + & + & + & + & + \\
\hline 3 & F & 65 & $\begin{array}{l}\text { CNSLD } \\
\text { Aspergilloma }\end{array}$ & + & - & - & + & + & + \\
\hline 4 & $\mathbf{F}$ & 57 & $\begin{array}{l}\text { Sarcoidosis } \\
\text { Aspergilloma }\end{array}$ & + & - & - & + & + & - \\
\hline 5 & $\mathbf{M}$ & 65 & Aspergilloma & + & - & - & + & + & + \\
\hline 6 & $\mathbf{M}$ & 74 & $\begin{array}{l}\text { Inactive TBC } \\
\text { Aspergilloma }\end{array}$ & + & - & - & + & + & + \\
\hline 7 & $\mathbf{M}$ & 51 & $\begin{array}{l}\text { Inactive TBC } \\
\text { Aspergilloma }\end{array}$ & + & - & - & + & + & + \\
\hline
\end{tabular}




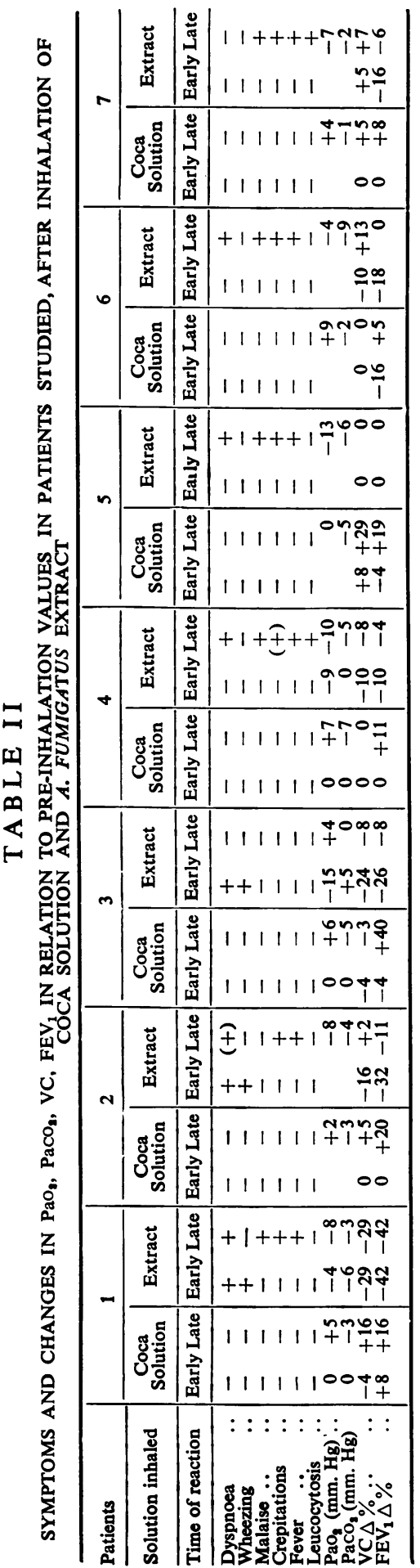

antigen administered (spore or mycelium extract). But in all the cases of repeated challenge (patients $1,2,3,5,6,7)$ a more rapid and higher increase in temperature was registered on the second day of challenge (Fig. 4 and Table III).

\section{T A B L E I I I}

MAXIMAL TEMPERATURE, AND TIME OF ITS OCCURRENCE AFTER PROVOCATION, ON FIRST AND SECOND RENCE AFTER PROVOCATION, ON FIRST AND SECO
DAYS, IN PATIENTS REACTING WITH FEVER

\begin{tabular}{|c|c|c|c|c|}
\hline \multirow{2}{*}{ Patient } & \multicolumn{2}{|c|}{ Max. Temp. $\left({ }^{\circ} \mathrm{C}\right)$} & \multicolumn{2}{|c|}{ Time of Max. Temp (hr) } \\
\hline & $\begin{array}{l}\text { 1st Provo- } \\
\text { cation }\end{array}$ & $\begin{array}{l}\text { 2nd Provo- } \\
\text { cation }\end{array}$ & $\begin{array}{l}\text { 1st Provo- } \\
\text { cation }\end{array}$ & $\begin{array}{l}\text { 2nd Provo- } \\
\text { cation }\end{array}$ \\
\hline $\begin{array}{l}1 \\
2 \\
3\end{array}$ & $\begin{array}{l}39 \cdot 2 \\
37 \cdot 8\end{array}$ & $\begin{array}{l}39.4 \\
37.9\end{array}$ & $\begin{array}{l}21 \\
17\end{array}$ & $\begin{array}{l}17 \\
14\end{array}$ \\
\hline $\begin{array}{l}3 \\
4 \\
5 \\
6 \\
7\end{array}$ & $\begin{array}{l}39 \cdot 8 \\
38 \cdot 2 \\
39 \cdot 3 \\
37 \cdot 5\end{array}$ & $\begin{array}{c}? \\
38 \cdot 4 \\
39 \cdot 7 \\
38 \cdot 0\end{array}$ & $\begin{array}{r}21 \\
19 \\
?\end{array}$ & $\begin{array}{r}? \\
17 \\
15 \\
?\end{array}$ \\
\hline
\end{tabular}

The chest radiograph did not show any changes after challenge.

\section{DISCUSSION}

Pepys et al. (1959) discussed asthmatic (type I) reactions after inhalation of Aspergillus extract attended or not with the intrapulmonary presence of and the formation of precipitins against this fungus. Patient 3 exemplified this type of reaction. It was rather tempting to assume that here the aspergilloma accounted for the sensitization. But we are not certain about this. For the Aspergillus asthma could have been present prior to the development of aspergilloma. The existence of early reactions to other antigens might favour this assumption.

Our findings after challenging patients with allergic aspergillosis were in keeping with some results obtained by Pepys et al. (1959), viz., combined early (type I) and late (type III) reactions. The late reaction of our allergic aspergillosis patients was in complete agreement with the results of the challenge tests on farmer's lung patients (Hilvering et al., 1966). Also the reaction of aspergilloma patients was entirely in conform. ity with this reaction.

The similarity of these late reactions makes it quite probable that these reaction patterns have an identical pathogenesis.

On repeated exposure farmer's lung patients show increasingly vigorous reactions. The earlier and higher rise in temperature in our patients on the second day of challenge also favours the assumption that we are dealing with one and the 


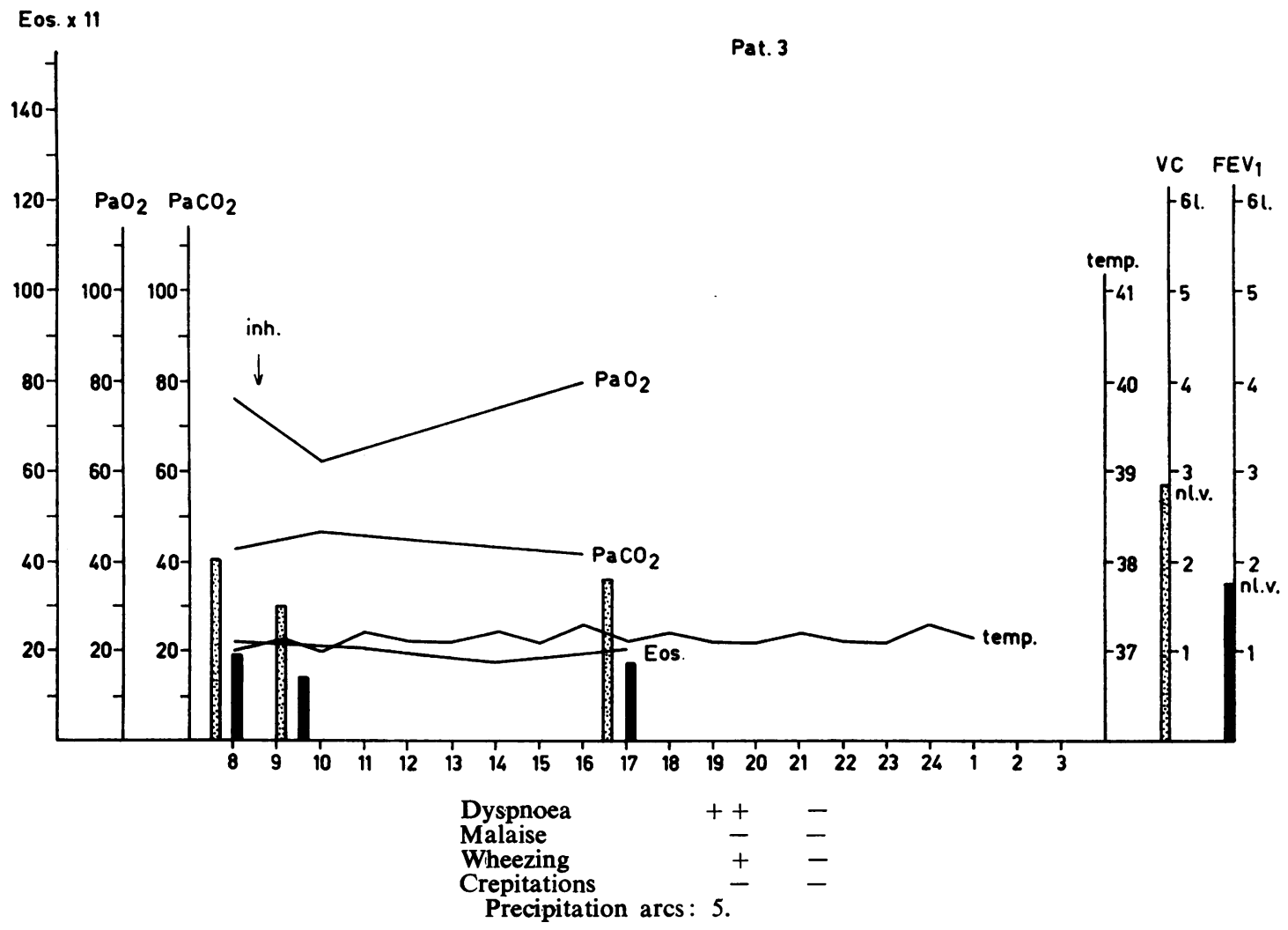

FIG. 1. Temperature, $\mathrm{PaO}_{2}, \mathrm{PaCO}_{2}, \mathrm{VC}, \mathrm{FEV}$, and number of eosinophils in patient 3 before and after inhalation. Symptoms - early and/or late - and the number of precipitation arcs present in the serum before the inhalation are shown in the lower part of the diagram.

same type of reaction. The arguments for the existence of a type III reaction in the vegetable dust syndromes are based on the obligatory presence of specific precipitating antibodies, the time interval between exposure and reaction, and the histological findings in the case of farmer's lung and pigeon breeder's lung (Seal, Hapke, and Thomas, 1968 ; Hapke, Seal, and Thomas, 1968 ; Barrowcliff and Arblaster, 1968). The last-mentioned findings, however, do not provide an adequate basis for excluding a type IV reaction. The gradual transition between the histological characteristics of these two reactions might account for this (Gell and Hinde, 1954).

Another argument has been the (inconsistent) late skin reaction in allergic aspergillosis patients (Pepys et al., 1959).

The number of precipitation arcs against Aspergillus extract found with the aid of double diffusion techniques is a measure of the total amount of precipitins in the sera of aspergillosis patients (Feinberg and Temple, 1963; Stevens, Hilvering, and Orie, to be published). There seems to be a correlation between the type of reaction in our patients and the number of precipitation arcs found. The type III reaction particularly occurs in those who show a high production of $N$ precipitins. The type $I$ reaction and the combined type I-type III reaction are found especially in those who show a low production of precipitins. This also holds for the group of five aspergilloma patients, in whom the antigen stimulus may be considered roughly equal. Although the group is too small to permit drawing pertinent conclusions, $\stackrel{?}{?}$ it could be that the pre-existent tendency of the $T$ individual to the production of precipitins or reagins partly determines the ultimate reaction to exposure to antigen (Table IV).

Pepys, Riddell, Citron, and Clayton (1962), too, found a lower production of precipitins in patients 


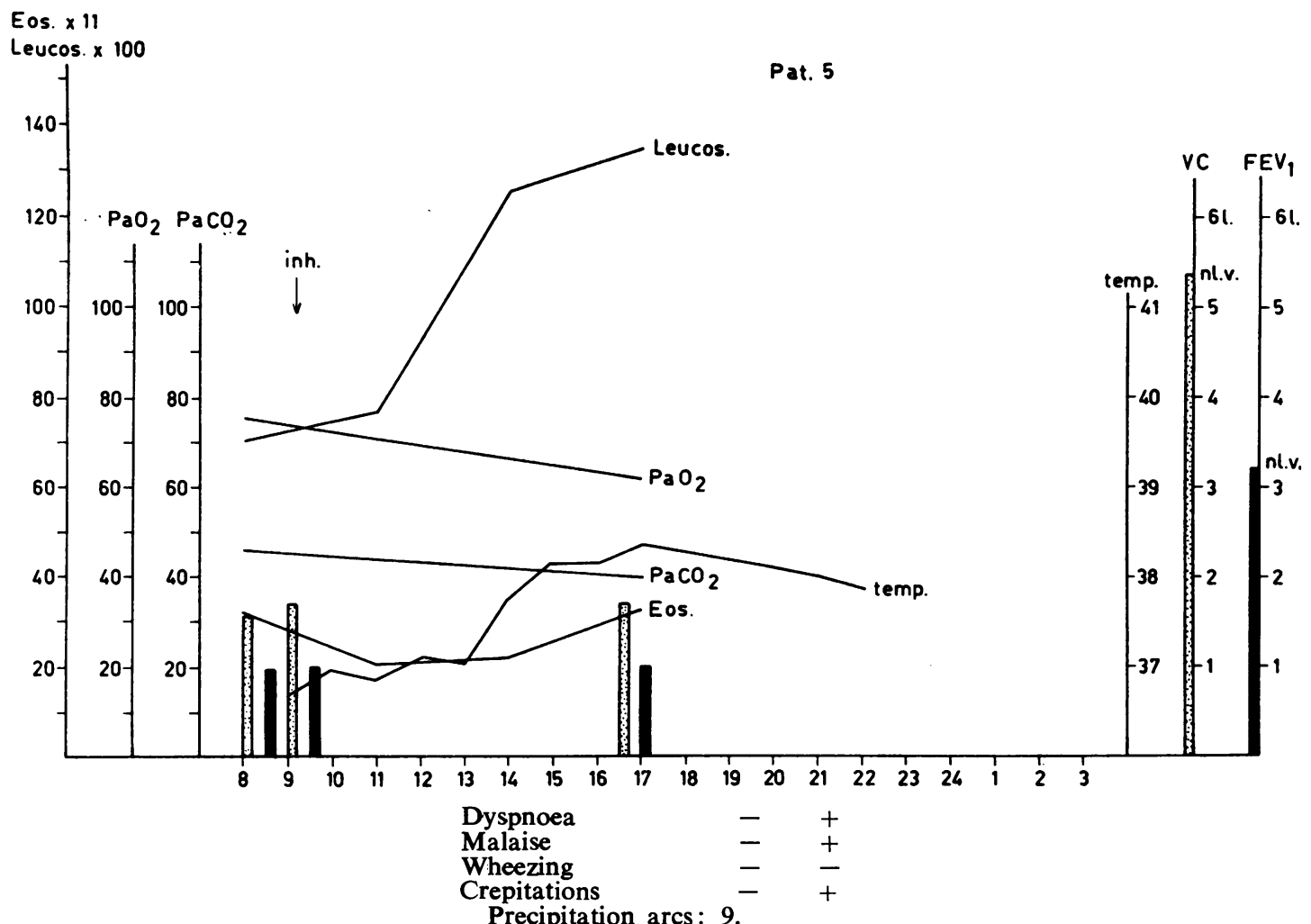

FIG. 2. Temperature, $\mathrm{PaO}_{2}, \mathrm{PaCO}_{2}, \mathrm{VC}, \mathrm{FEV}$, and number of eosinophils and leucocytes in patient 5 before and after inhalation. Symptoms-early andlor late-and the number of precipitation arcs present in the serum before the inhalation are shown in the lower part of the diagram.

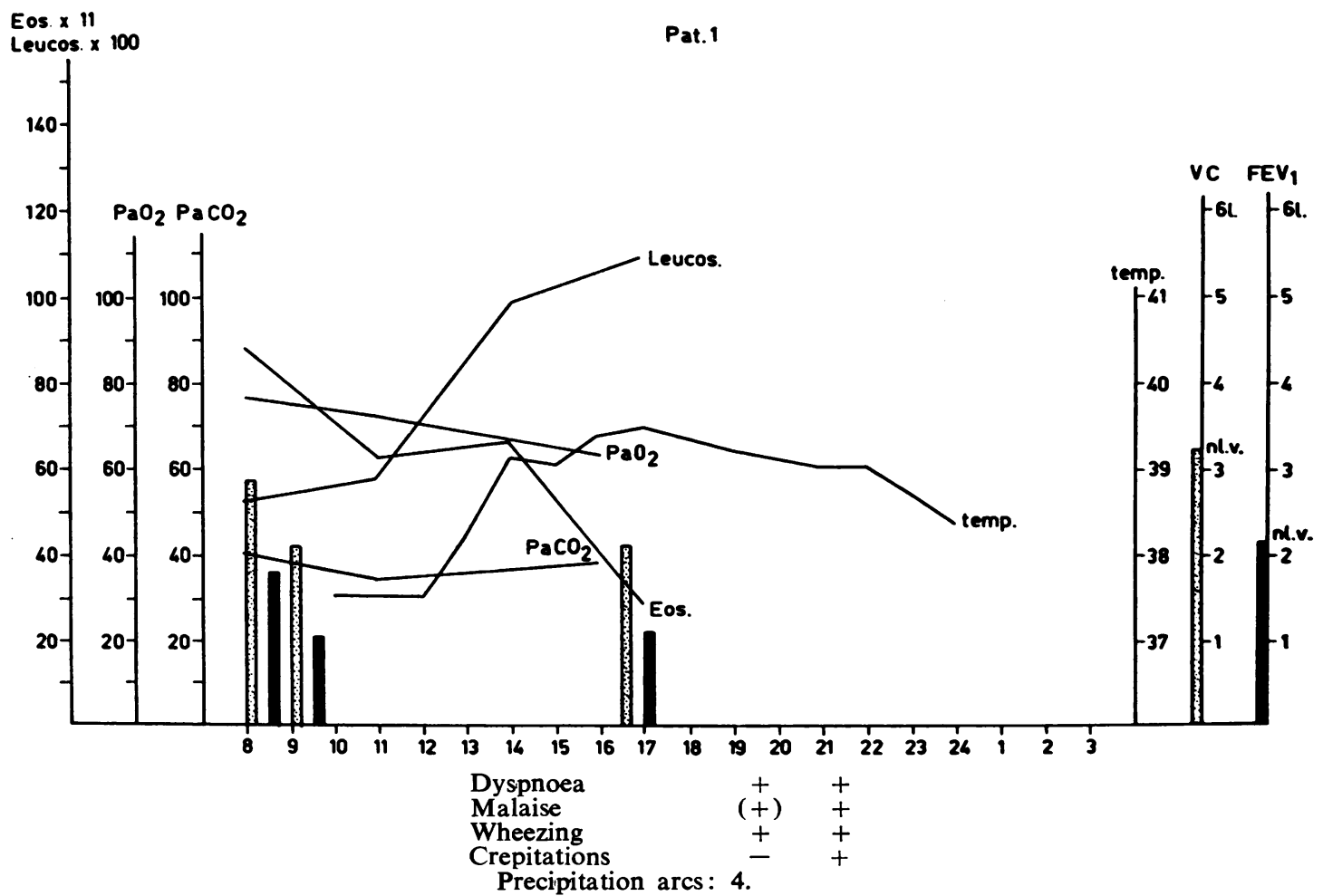

FIG. 3. Temperature, $\mathrm{PaO}_{2}, \mathrm{PaCO}_{2}, \mathrm{VC}, \mathrm{FEV}$, and number of eosinophils and leucocytes in patient 1 before and after inhalation. Symptoms - early and/or late-and the number of precipitation arcs present in the serum before the inhalation are shown in the lower part of the diagram. 

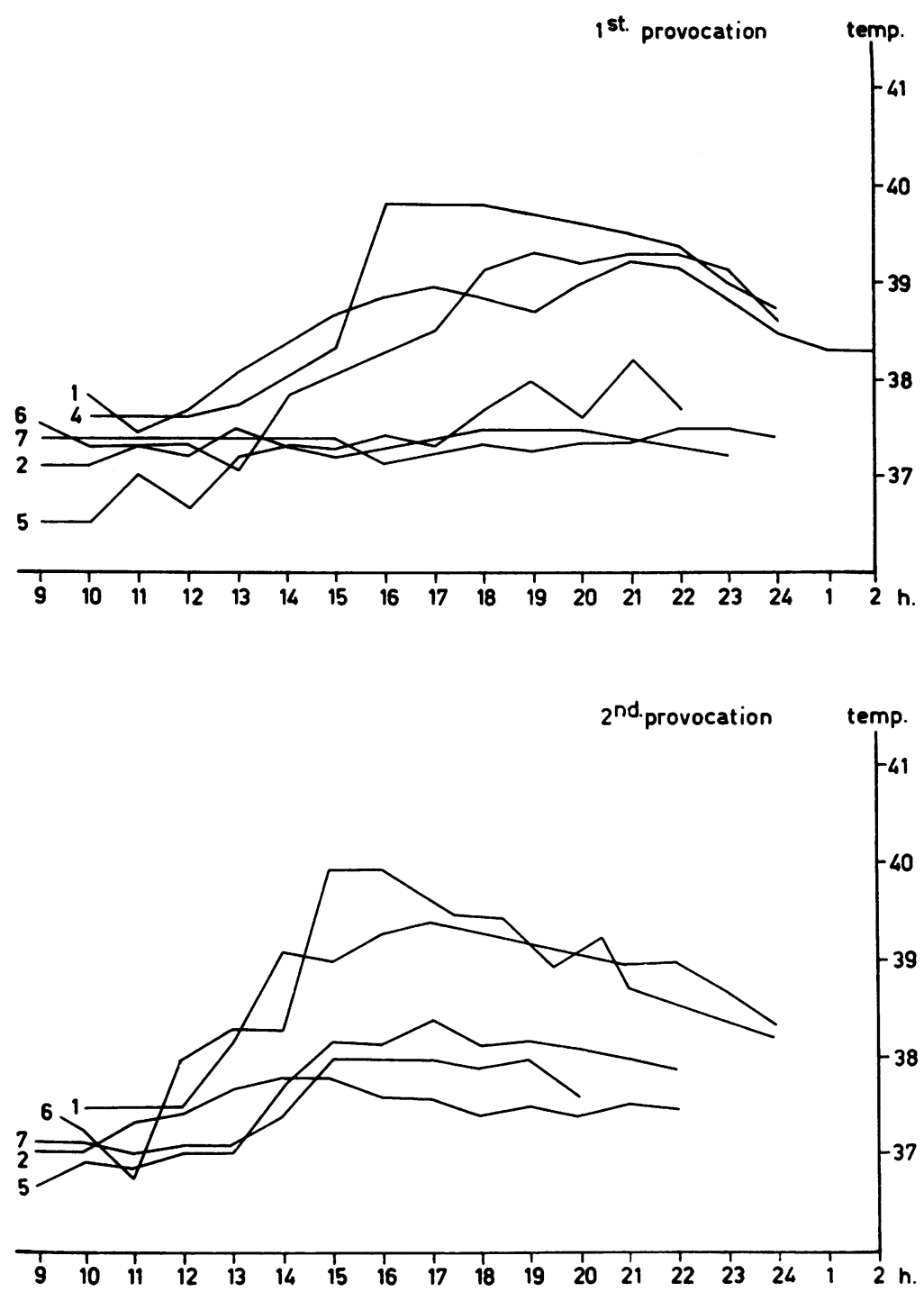

FIG. 4. Course of temperature after provocation, on first and second day, in patients reacting with fever.

T A B LE IV

CORRELATION BETWEEN TYPE OF REACTION-EARLY AND/OR LATE-AND NUMBER OF PRECIPITATION ARCS

\begin{tabular}{c|c|c|c}
\hline Patient & $\begin{array}{c}\text { Early Reaction } \\
\text { (type I) }\end{array}$ & $\begin{array}{c}\text { Late Reaction } \\
\text { (type III) }\end{array}$ & $\begin{array}{c}\text { No. of Pre- } \\
\text { cipitation Arcs }\end{array}$ \\
\cline { 2 - 3 } & + & + & 4 \\
2 & + & + & 5 \\
3 & + & + & 5 \\
4 & + & + & 9 \\
5 & + & + & 8 \\
6 & - & + & 9 \\
7 & & & \\
\hline
\end{tabular}

with Aspergillus asthma and allergic aspergillosis. But here also patients were involved in whom growth of the fungus in the lungs had not been 0 established, so that the antigen stimulus in this series is not comparable.

Therefore, the results of these challenge tests support the view that a continued fever in aspergilloma patients, which is to be treated with

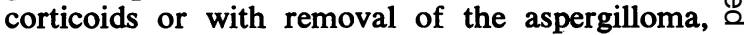
may possibly be attributed to a reaction induced 
by precipitins, i.e., a type III reaction (Hilvering et al., p. 19 in this issue).

As a matter of fact, the two patients in question both had a high production of precipitins (6 and 16 precipitins were demonstrated, respectively). Our clinical observation (Hilvering et al., p. 19 in this issue) and the reaction of aspergilloma patients to inhalation of antigens weaken one of the arguments against the existence of a type III reaction in the case of allergic aspergillosis, namely, that in a patient with an aspergilloma spontaneous febrile reactions are never observed. They are observed indeed, and moreover can be brought about by administering antigens. The reason why these type III reactions are observed in aspergilloma patients less often than in patients with allergic aspergillosis is still not clear. However, it should be borne in mind that the local intrapulmonary situation is not the same in this type of patient and that, more particularly, an extrinsic airways obstruction (caused, for instance, by inhalation of spores) may produce an 'antigen release' from the intrabronchial growth of the fungus far more readily in a patient with allergic aspergillosis than in one with an intracavitary aspergilloma.

A progressive fibrosis, as is found in farmer's lung and pigeon breeder's lung patients after a relatively long time, has not been observed in patients with aspergillosis, where the exposure is local (aspergilloma or local bronchiectases in which there is an Aspergillus growth), whereas in the former cases the antigen is inhaled and distributed diffusely throughout both lungs. It could also be that the quantities of antigen administered play a role here.

Pulmonary infiltrations were not seen after challenging but were observed in one of the spontaneously febrile patients. It is still uncertain whether these infiltrations in allergic aspergillosis form part of the type III reaction (Pepys et al., 1959) or whether they are caused by a proximal airways obstruction brought about by the intrabronchial presence of the fungus and a superimposed reversible bronchial constriction (Campbell and Clayton, 1964 ; Henderson, 1968). Finally, it may be asked whether the rise in temperature after inhalation of the Aspergillus extract is caused by toxic substances. In our opinion, the absence of any temperature rise in patient 3 , and the great similarity of the entire reaction pattern, inclusive of the temperature rise, to that of the vegetable dust syndromes, makes this very improbable.

\section{CONCLUSIONS}

1. In aspergilloma patients inhalation of Aspergillus extract may give rise to a clinical picture which is fully identical with that observed after exposure of patients having a vegetable dust syndrome and with the late reaction observed in the case of allergic aspergillosis.

2. These findings support our opinion that continued fever in aspergilloma patients may, other causes being excluded, be accounted for by a type III reaction, sustained by the aspergilloma, of the patients to the Aspergillus antigen.

3. It is not impossible that the type of reaction after exposure is also dependent on the individual tendency to produce mainly either precipitins or reagins after an antigen contact.

4. The differences, in the acute phase and also in the later stages, between the known vegetable dust syndromes, allergic aspergillosis, and the syndrome of continued fever in the aspergilloma patient could be accounted for by the localization of the antigen-antibody reaction in the lungs.

\section{REFERENCES}

Barrowcliff, D. F., and Arblaster, P. G. (1968). Farmer's lung: a study of an early acute fatal case. Thorax, 23, 490.

Biguet, J., Tran van Ky, P., Capron, A., and Fruit, J. (1962). Analyse immunochimique des fractions antigéniques solubles d'Aspergillus fumigatus. Ordre d'apparition des anticorps expérimentaux des lapins: comparaison de ces derniers avec des anticorps naturels humains. C.R. Acad. Sci. (Paris), 254, 3768.

Bishop, J. M., Melnick, S. C., and Raine, J. (1963). Farmer's lung: studies on pulmonary function and aetiology. Quart. J. Med., 32, 257.

Bringhurst, L. S., Byrne, R. N., and Gershon-Cohen, J. (1959). Respiratory disease of mushroom workers: Farmer's lung. J. Amer. med. Ass., 171, 15.

Buechner, H. A. (1960). Bagassosis. Peculiarities of its geographical pattern and report of the first case from Peru and Puerto Rico. pattern and report
Ibid., 174, 1237.

Campbell, M. J., and Clayton, Y. M. (1964). Bronchopulmonary aspergillosis. Amer. Rev. Resp. Dis., 89, 186.

Dijkman, J. H., Stevens, E. A. M., Hilvering, G., and Orie, N. G. M. (1968). The demonstration of precipitins in the serum as an aid in the diagnosis of the growth of Aspergillus in the lung. Ned. T. Geneesk., 112, 2351.

Emanuel, D. A., Lawton, B. R., and Wenzel, F. J. (1962). Maplebark disease. New Engl. J. Med., 266, 333.

Feinberg, J. G., and Temple, A. (1963). An investigation on precipitins to moulds in asthmatic sera. Int. Arch. Allergy, 22, 274.

Gell, P. G. H., and Coombs, R. R. A. (1964). Clinical Aspects of Immunology (revised reprint), pp. 320, 402. Blackwell, Oxford. and Hinde, I. T. (1954). Observations on the history of the Arthus reaction and its relation to other known types of skin hypersensitivity. Int. Arch. Allergy, 5, 23.

Gernez-Rieux, Ch., Biguet, J., Voisin, C., Capron, A., Balgairies, E., and Tran van Ky, P. (1963). Diagnostique sérologique des aspergillomes broncho-pulmonaires par immuno-electrophorëse. J. franc. Méd. Chir. thor., 17, 663.

and Tran van Ky, P. (1963). Diagnostic immunologique des aspergillomes broncho-pulmonaires. Presse méd., 71,1541 .

Hapke, E. J., Seal, R. M. E., and Thomas, G. O. (1968). Farmer's lung. Thorax, 23, 451 .

Henderson, A. H. (1968). Allergic aspergillosis: review of 32 cases. Ibid., 23, 501.

Hilvering, C., de Vries, K., and Orie, N. G. M. (1966). Boerenlong ("Farmer's lung"). Ned. T. Geneesk., 110, 1297. 
Stevens, E. A. M., and Orie, N. G. M. (1970). Fever in aspergillus mycetoma. Thorax, 25, 19.

Longbottom, J. L., and Pepys, J. (1964). Pulmonary aspergillosis: Diagnostic and immunological significance of antigens and C-substance in Aspergillus fumigatus. J. Path. Bact., 88, 141. _ and Clive, F. Temple (1964). Diagnostic precipitation test in aspergillus pulmonary mycetoma. Lancet, 1, 588.

Parish, W. E. (1963). Farmer's lung. Thorax, 18, 83. Pepys, J., Riddell, R. W., Citron, K. M., and Clayton, Y. M. (1961).
Precipitins against extracts of hay and fungi in the serum of patients with farmer's lung. Acta allerg. (Kbh.), 16, 76.

(1962). Precipitins against extracts of hay and moulds in the serum of patients with farmer's lung, aspergillosis, asthma, and sarcoidosis. Thorax, 17, 366 .
- and Short, E. I. (1959). Clinical and immunologic significance of Aspergillus fumigatus in the sputum. Amer. Rev. resp. Dis., 80, 167.

Raper, K. B., and Fennell, D. I. (1965). The Genus Aspergillus, p. 42. Williams and Wilkins, Baltimore.

Reed, C. E., Sosman, A., and Barbee, R. A. (1965). Pigeon-breeders lung. J. Amer. med. Ass., 193, 261.

Seal, R. M. E., Hapke, E. J., and Thomas, G. O. (1968). The pathology of the acute and chronic stages of farmer's lung. Thorax, 23, 469.

Stevens, E. A. M., Russchen, C. J., Hilvering, C., and Orie, N. G. M. Stero id effect on Aspergillus antibodies. Scand. J. Resp. Dis., in press. 